Indo. J. Chem. Res, 2018, 6(1), 12-21

\title{
KINETIKA ADSORPSI ZAT WARNA METILEN BIRU OLEH KARBON AKTIF DARI KULIT KEMIRI (Aleurites moluccana $(L)$ Willd)
}

\author{
Kinetics of Blue Methylene Dyes Adsorption Substances By Actived Carbon From \\ Hazelnut Shell (Aleurites moluccana (L) Willd)
}

\author{
Jolantje Latupeirissa*, Matheis F.J.D.P. Tanasale, Sigit Hardianto Musa, \\ Department of Chemistry, Faculty of Matemathics and Natural Sciences, University of Pattimura-Indonesia \\ *Corresponding author, e-mail: latupeirissajola@gmail.com
}

Received: April 2018 Published: July 2018

\begin{abstract}
The adsorption of methylene blue dye by active carbon of hazelnut shell has been done. Through acquired active carbon composing process, where is the hazelnut shell at entry into furnace on temperature $350{ }^{\circ} \mathrm{C}$ for 2 hour, afterwards is cooled and at sieves by sieve 100 mesh. Then by the calsination process in furnace with temperature $450{ }^{\circ} \mathrm{C}$ one was streamed to gas $\mathrm{N}_{2}$ four 2 hours then characterized by X-ray diffraction (XRD) for carbon before activation. The next activated with $\mathrm{KOH}$ solution with a concentration of $50 \%$ four 5 hour, then dried in an ovenat $120{ }^{\circ} \mathrm{C}$ for 1 hour and thencharacterized. The weight of the solidacidity before and after activation consecutive $\left(5.3848 \times 10^{-3}\right.$ dan $\left.42.1554 \times 10^{-3}\right)$ mol g ${ }^{-1}$. Isotherm adsorption of methylene blue dyes on active carbon was following the Freundlich isotherm. Adsorption kinetics of methylene blue dyes on active carbon in various concentration of hazelnut shell was controlled with temperature variety at $25{ }^{\circ} \mathrm{C}$ and $30{ }^{\circ} \mathrm{C}$. The result showed that energy activation was $-46.24310602 \mathrm{~mol}^{-1}$ and a value is $1.61975 \times 10^{10} \mathrm{~g} \mathrm{mg}^{-1} \mathrm{menit}^{-1}$. Adsorption mechanism of methylene blue dyes on active carbon at various concentration of hazelnut shell is chemical adsorption process.
\end{abstract}

Keywords: Actived carbon, hazelnut shell, methylene blue, adsorption kinetics.

\section{PENDAHULUAN}

Pada saat ini pembangunan di Indonesia mengalami kemajuan yang sangat pesat. Hal ini diiringi dengan semakin meningkatnya perkembangan dan kemajuan di bidang industri. Perkembangan dan kemajuan di bidang industri tersebut akan mempengaruhi limbah yang dihasilkan oleh industri, baik dari segi kuantitas maupun kualitas limbah. Limbah yang dihasilkan oleh industri tersebut akan mempunyai resiko sebagai penyebab pencemaran lingkungan.

Limbah merupakan masalah utama dalam pengendalian dampak lingkungan industri. Umumnya, limbah yang dihasilkan adalah limbah zat warna. Zat warna merupakan senyawa organik atau anorganik berwarna yang digunakan untuk memberi warna tekstil atau suatu makanan, minuman, obat-obatan, kosmetika, dan lain-lain (Fessenden \& Fessenden, 1984). Salah satu zat warna yangpaling sering digunakan pada industri tekstil adalah metilen biru (Demirbas, 2008).
Berbagai metode telah banyak dilakukan untuk menangani permasalahan limbah industri khususnya penghilangan zat warna, antara lain dengan metode koagulasi, penukar ion, dan ozonasi (Widhianti, 2010). Tetapi metodemetode tersebut membutuhkan biaya yang relatif tinggi dalam pengoperasiannya. Penggunaan bahan biomaterial sebagai penyerap zat warna merupakan alternatif yang memberikan harapan terhadap pengolahan limbah. Penggunaan biomassa sebagai penjerap zat warna metilen biru merupakan alternatif yang sekarang banyak dikembangkan, karena lebih selektif, pendekatannya kompetititf, efektif, dan murah, seperti: tempurung kelapa, kulit kenari, sekam padi, kulit kacang tanah, kulit kemiri, dan juga kulit kakao (Rafattulah dkk, 2009, ). Selama ini, kulit kemiri banyak dibuang dan belum banyak dimanfaatkan secara optimal, padahal kulit kemiri memiliki potensi yang sangat melimpah dan merupakan salah satu bahan pembuatan karbon aktif yang dapat digunakan dalam proses adsorpsi. Latupeirisa 


\section{J. Latupeirissa dkk. / Indo. J. Chem. Res, 2018, 6(1), 12-21}

dkk (2017) telah mengkarakterisasi karbon aktif dari kulit kemiri dengan menggunakan XRD.

Karbon aktif adalah suatu bahan padat berpori yang merupakan hasil pembakaran bahan yang mengandung karbon. Dengan pengolahan tertentu yaitu proses aktivasi seperti perlakuan dengan tekanan dan suhu tinggi, dapat diperoleh karbon aktif yang memiliki permukaan dalam yang luas. Aktivasi karbon aktif dapat dilakukan melalui 2 proses yaitu aktivasi kimia dan aktivasi fisika (Rini dan Sutapa, 2005).

Chandra dkk., (2009) telah melakukan penelitian tentang Proses Preparasi dan Karakterisasi karbon aktif dari kulit durian untuk menghilangkan zat warna metilen biru, dengan demikian penilitian ini hanya mengkaji aspek kondisi optimum untuk mendapatkan luas permukaan karbon aktif dari kulit durian, tanpa mengkaji proses adsorpsi dan kinetikanya, padahal dengan mengetahui aspek adsorpsi, maka dapat diketahui Proses kesetimbangan yang menjelaskan proses adsorpsi yang mengikuti suatu isoterm adsorpsi dan untuk aspek kinetikanya, dapat diketahui seberapa cepatnya proses adsorpsi zat warna metilen biru berlangsung, dan bagaimana mekanismenya.

Dengan memanfaatkan karbon aktif dari kulit kemiri sebagai adsorben pada proses adsorpsi, maka sangat diharapkan dapat mengatasi masalah pencemaran lingkungan oleh zat warna. Pada penelitian ini telah dilakukan penentuan kinetika adsorbsi metilen biru oleh karbon aktif dari kulit kemir (Aleurites Moluccana (L) willd)

\section{METODOLOGI}

\section{Bahan}

Kulit kemiri, akuades, $\mathrm{KOH}$ p.a (E. Merck), gas nitrogen, amoniak p.a (E. Merck), dan zat warna metilen biru.

\footnotetext{
Alat

Spektrofotometer UV-VIS (Shimadzu UV1201), desikator, ayakan, neraca analitik Ohaus, shaker (SHA-C, Constant Temperature Oscillator), seperangkat alat gelas, pipet volum, hotplate (Barnstead Thermolyne 47900 Furnace Cimarec), tanur (Barnstead Thermolyne 47900 Furnace) dan XRD (Shimadzu XD - 160)
}

\section{Prosedur kerja \\ Preparasi sampel}

Kulit kemiri diambil dari buah kemiri. Lepaskan isinya, lalu diambil kulitnya. Kulit kemiri dicuci berulang kali dengan air suling, kemudian diarangkan dalam tanur pada suhu $350^{\circ} \mathrm{C}$ selama 2 jam, dikeluarkan dan didinginkan pada suhu ruang, kemudian dihaluskan dan diayak dihaluskan sampai menjadi bubuk (100 mesh). Setelah itu dilakukan proses kalsinasi yaitu, sampel dimasukan dalam perangkat alat kalsinasi yang dipanaskan pada suhu $450^{\circ} \mathrm{C}$ dan dialiri dengan gas nitrogen, selama 2 jam. Kemudian dikarakterisasi dengan menggunakan X-RD dan selanjutkan disimpan dalam desikator untuk penelitian selanjutnya.

\section{Uji keasaman permukaan sebelum diaktivasi}

Metode yang digunakan untuk menentukan keasaman permukaan dari karbon aktif adalah metode gravimetri. Karbon yang dihasikan dari kulit kemiri, diambil sebanyak 0,2 gram, dimasukkan dalam wadah dan diletakkan dalam desikator yang di dalamnya terdapat adsorbat ammonia (p.a). Desikator ditutup selama 24 jam, kemudian dikeluarkan dan dibiarkan selama 2 jam pada tempat terbuka untuk melepaskan basa yang teradsorpsi fisik. Bobot karbon yang telah mengadsorpsi basa diukur untuk mendapatkan mol basa yang teradsorpsi pada karbon dengan menggunakan rumus:

Bobot teradsorpsi $=\frac{w_{3}-w_{2}}{\left(w_{2}-w_{1}\right) \times B M}$

dengan :

$\mathrm{W}_{1}=$ Bobot kosong

$\mathrm{W}_{2}=$ Bobot wadah dan cuplikan

$\mathrm{W}_{3}=$ Bobot wadah dan cuplikan yang telah mengadsorpsi

amoniak

$\mathrm{BM}=$ Bobot molekul ammonia

\section{Proses aktivasi karbon kulit kemiri}

Sebanyak $25 \mathrm{~g}$ bubuk karbon kulit kemiri dicampur dengan $\mathrm{KOH} \quad 50 \% \quad 100 \quad \mathrm{~mL}$ dimasukkan ke dalam labu bulat $250 \mathrm{~mL}$ yang dilengkapi dengan pengaduk, diaduk pada 200 rpm dengan perbandingan waktu 5 jam pada suhu kamar (sekitar $30^{\circ} \mathrm{C}$ ) dengan perbandingan $\mathrm{KOH}$ dalam larutan 1:2. 


\section{J. Latupeirissa dkk. / Indo. J. Chem. Res, 2018, 6(1), 12-21}

\section{Uji keasaman permukaan setelah diaktivasi}

Metode yang digunakan untuk menentukan keasaman permukaan dari karbon aktif adalah metode gravimetri. Karbon aktif yang dihasilkan dari kulit kemiri, diambil sebanyak 0,2 g dimasukkan dalam wadah dan diletakan dalam desikator yang di dalamnya terdapat adsorbat ammonia (p.a). Desikator ditutup selama 24 jam, kemudian dikeluarkan dan dibiarkan selama 2 jam pada tempat terbuka untuk melepaskan basa yang teradsorpsi fisik.

\section{Karakterisasi karbon aktif}

Karakterisasi struktur pori karbon aktif yang dihasilkan, ditentukan oleh Penerapan Xray diffraction $(\mathrm{XRD})$.

\section{Pembuatan larutan standar zat warna metilen biru}

Larutan standar zat warna metilen biru dibuat dengan cara membuat larutan induk dengan menimbang $0,1 \mathrm{~g}$ zat warna metilen biru ke dalam beaker gelas kemudian dipindahkan ke dalam labu takar $100 \mathrm{~mL}$ ditambahkan akuades sampai tanda batas, maka diperoleh larutan standar dengan konsentrasi 1000 ppm. Larutan $5 \mathrm{~mL}$ diambil dari larutan induk ke dalam labu takar $100 \mathrm{~mL}$ dan diencerkan sampai tanda batas maka didapatkan larutan 50 ppm, kemudian diukur absorbansinya pada panjang gelombang antara 500-700 nm menggunakan spektrofotometer UV-Vis.

\section{Pembuatan kurva standar zat warna metilen biru}

Diambil $1 \mathrm{~mL}$ larutan zat warna metilen biru dari larutan induk $50 \mathrm{ppm}$ ke dalam labu takar $100 \mathrm{~mL}$ dan encerkan sampai tanda batas maka didapatkan larutan zat warna metilen biru $0,5 \mathrm{ppm}$. Hal yang sama dilakukan untuk konsentrasi 1,0 ppm (diambil $2 \mathrm{~mL}$ ); 1,5 ppm (diambil $3 \mathrm{~mL}$ ); 2,0 ppm (diambil $4 \mathrm{~mL}$ ); dan 2,5 ppm (diambil $5 \mathrm{~mL}$ ) setelah itu diukur absorbansi masing-masing konsentrasi menggunakan spektrofotometer UV-Vis pada panjang gelombang maksimum $665 \mathrm{~nm}$.

\section{Adsorpsi zat warna metilen biru oleh karbon aktif dari kulit Kemiri.}

Sebanyak $25 \mathrm{~mL}$ larutan zat warna metilen biru dengan konsentrasi 25 ppm, 55 ppm, 100 ppm, 150 ppm, dan 200 ppm, dimasukkan ke dalam erlemeyer yang berbeda, kemudian ditambahkan0,1 g karbon aktif pada masingmasing erlemeyer, dikocok selama 2 jam, didiamkan, dan disaring menggunakan kertas saring Whatman no.42. Konsentrasi larutan setelah diadsorpsi ditentukan dengan menggunakan Spektrofotometer UV-Vis pada panjang gelombang $665 \mathrm{~nm}$.

\section{Penentuan orde dan tetapan laju adsorpsi}

Untuk penentuan orde dan tetapan laju reaksi dilihat pada konsentrasi zat warna metilen biru dan jumlah karbon aktif yang mempunyai adsorpsi optimum yang diperoleh berdasarkan langkah kerja adsorpsi. Selanjutnya, zat warna metilen biru yang mempunyai adsorpsi optimum, diambil sebanyak $25 \mathrm{~mL}$, dimasukkan dalam erlemeyer kemudian tambahkan $0,1 \mathrm{~g}$ karbon aktif. Setelah itu, dikocok selama 30 menit pada suhu $25{ }^{\circ} \mathrm{C}$. Larutan yang dihasilkan, kemudian disaring dengan kertas saring Whatman no.42. Konsentrasi larutan setelah diadsorpsi, ditentukan dengan menggunakan Spektrofotometer UV-Vis pada panjang gelombang $665 \mathrm{~nm}$. Hal yang sama dilakukan untuk waktu 60, 90, 120,150, 180, 240, 360 menit.

\section{Penentuan energi aktivasi}

Langkah Penentuan orde dan tetapan laju adsorpsi dilakukan dengan memvariasikan suhu pada $30{ }^{\circ} \mathrm{C}$

\section{HASIL DAN PEMBAHASAN}

\section{Preparasi karbon dari kulit kemiri}

Kulit kemiri yang telah dicuci, dikeringkan dan dilakukan proses pengarangan dengan menggunakan tanur pada suhu $350^{\circ} \mathrm{C}$ selama 2 jam hingga menjadi arang. Arang yang sudah terbentuk kemudian ditumbuk dan diayak dengan ayakan yang berukuran 100 mesh, Selanjutnya, dilakukan suatu proses yaitu proses kalsinasi yang bertujuan untuk menghilangkan uap air, pengotor-pengotor lain sehingga yang tersisa hanya karbon.

Proses kalsinasi ini dilakukan dengan pemanasan arang pada suhu $450^{\circ} \mathrm{C}$ selama 2 jam serta dialiri gas nitrogen $\left(\mathrm{N}_{2}\right)$. Arang dimasukan dalam reaktor telah dihubungkan dengan tabung nitrogen. Reaktor kemudian ditempatkan pada furnace yang suhunya telah diatur, yang dihubungkan pula dengan regulator 


\section{J. Latupeirissa dkk. / Indo. J. Chem. Res, 2018, 6(1), 12-21}

untuk menyelaraskan suhu tanur dengan pencatat suhu yang telah ditentukan yang terhubung pula dengan stabilizer untuk menstabilkan tegangan listrik yang masuk ke dalam furnace. Setelah itu didinginkan pada suhu kamar. Karbon yang dihasilkan dari proses kalsinasi kemudian dikarakterisasi dengan XRD yang diperlihatkan pada Gambar 1, setelah itu disimpan untuk penelitian selanjutnya. Analisis difraksi sinar $\mathrm{X}$ dilakukan dengan menggunakan alat XRD dengan panjang gelombang 1,54060 $\AA$ menggunakan radiasi dari tabung target $\mathrm{Cu}$, tegangan $40,0 \mathrm{kV}$, arus $30,0 \mathrm{~mA}$ dan daerah pengamatan antara 3,0200 - 90,0000 derajat, selama 0,24 detik.

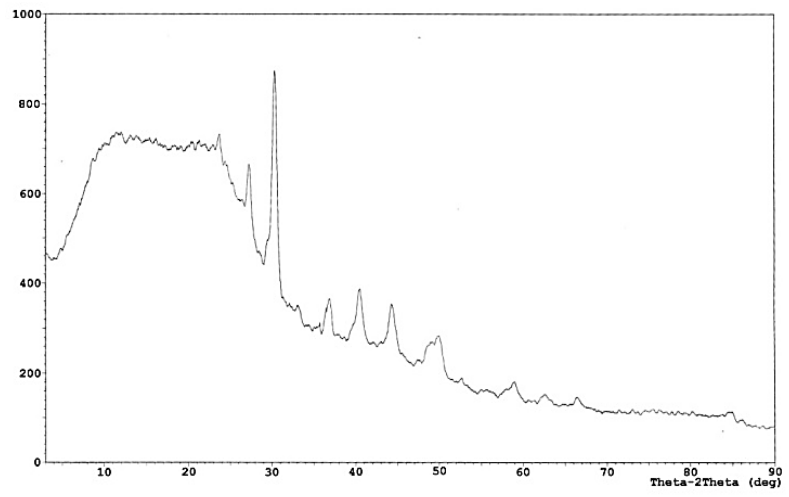

Gambar $\begin{gathered}\text { 1. Difraktogram XRD karbon } \\ \text { sebelum aktivasi }\end{gathered}$

Berdasarkan difraktogram XRD yang diperlihatkan pada Gambar 1 data kristalitas untuk sampel karbon sebelum aktivasi meliputi pemisahan interlayer karbon yaitu berturut-turut untuk tiga peak utama yaitu $2,95 \AA$, $3,75 \AA$, dan $3,27 \AA$, ketiga peak tersebut berada pada daerah $2 \Theta$ masing-masing adalah $30,2782^{\circ}, 23,7000^{\circ}$, dan $27,2200^{\circ}$.

\section{Aktivasi karbon dari kulit kemiri}

Pada pembuatan karbon aktif, tahapannya adalah tahap aktivasi secara kimia dengan penambahan larutan $\mathrm{KOH} 50 \%$ selama 5 jam. Tahap aktivasi bertujuan untuk memperbesar pori-pori karbon sehingga kualitas kulit kemiri dapat digunakan sebagai adsorben. Secara umum, proses aktivasi ada dua macam yaitu aktivasi kimia dan fisika, aktivasi kimia adalah proses pemutusan rantai karbon dari senyawa organik dengan pemakaian bahan-bahan kimia. Aktivasi fisika adalah proses pemutusan rantai karbon dari senyawa organik dengan bantuan panas, uap, dan $\mathrm{CO}_{2}$. Setalah itu, karbon aktif tersebut dikarakterisasi dengan menggunakan alat XRD dan hasilnya memiliki puncak lebih ramping daripada karbon sebelum aktivasi dengan $\mathrm{KOH}$. Hal ini menunjukkan bahwa karbon sesudah aktivasi mempunyai kristalinitas yang lebih baik dari karbon sebelum aktivasi. Hal tersebut disebabkan $\mathrm{KOH}$ telah membersihkan pengotor-pengotor, sehingga struktur karbon tersebut akan menjadi semakin baik, yang diperlihatkan pada Gambar 2.

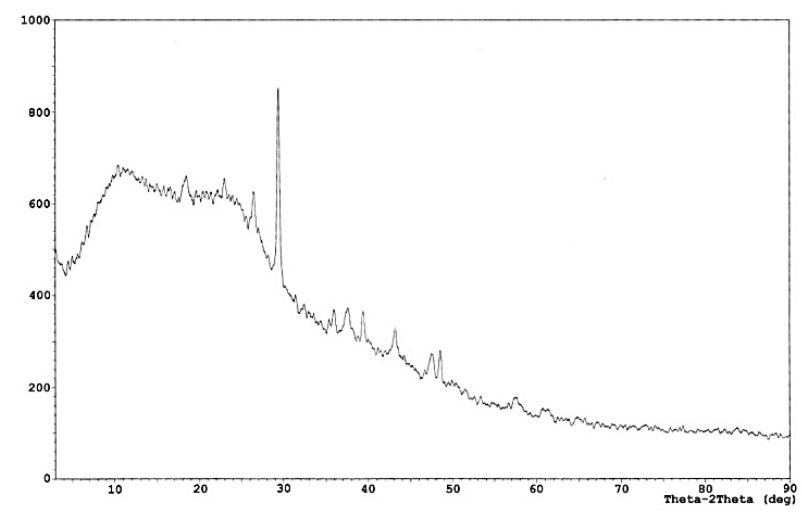

Gambar 2. Difraktogram XRD karbon sesudah aktivasi

Dari Gambar 2, menunjukan bahwa terdapat juga tiga peak utama yang nilanya berturut-turut $3,04 \AA$, $3,36 \AA$ dan $8,53 \AA$ dan masing-masing berada pada nilai $2 \Theta$ dengan nilai yang bergeser yaitu $29,3898 \AA, 26,5062 \AA$, dan $10,3600 \AA$ yang berbeda dengan nilai $2 \Theta$ pada difraktogram karbon sebelum aktivasi. Pergeseran ini menunjukan terjadinya perbedaan jarak antar muka kristal karbon. Jarak antar muka ini disebabkan oleh zat aktivator $\mathrm{KOH}$.

\section{Penentuan keasaman padatan karbon aktif}

Keasaman padatan dapat dinyatakan sebagai banyaknya gugus-gugus asam yang terdapat dalam setiap satuan berat sampel. Pengukuran sampel karbon sebelum dan sesudah aktivasi dilakukan dengan metode gravimetri yaitu adsorpsi uap amoniak. Keasaman sampel karbon sebanding dengan banyaknya uap amoniak yang teradsorpsi oleh sampel karbon,dimana pengukuran dilakukan dalam keadaan vakum sehingga tidak ada basa lain dan uap air yang berkompetisi dengan amoniak. 


\section{J. Latupeirissa dkk. / Indo. J. Chem. Res, 2018, 6(1), 12-21}

Keasaman padatan untuk mengetahui kemampuan adsorpsi karbon aktif yang dilakukan dengan metode gravimetri. Rusman (1999), menyatakan bahwa jumlah asam dari suatu padatan dapat diperoleh dengan cara mengukur jumlah basa yang teradsorpsi secara kimia (kemisorpsi), dalam fase gas.

Tabel 1. Perbandingan keasaman bobot teradsorpsi karbon sebelum dan setelah aktivasi.

\begin{tabular}{|c|c|c|c|c|}
\hline $\begin{array}{l}\text { Sampel } \\
\text { kosong }\end{array}$ & $\begin{array}{c}\text { Cawan } \\
\text { kosong } \\
\text { (W1) gram }\end{array}$ & $\begin{array}{c}\text { Cawan + } \\
\text { sampel }(W 2) \\
\text { gram }\end{array}$ & $\begin{array}{c}\text { Cawan }+ \\
\text { sampel yg } \\
\text { telah } \\
\text { teradsorpsi } \\
\end{array}$ & $\begin{array}{c}\text { Bobot } \\
\text { teradsorpsi } \\
\times \mathbf{1 0}^{-3}\left(\mathrm{molg}^{-1}\right)\end{array}$ \\
\hline $\begin{array}{l}\text { Karbon } \\
\text { sebelum } \\
\text { diaktivasi }\end{array}$ & 34,3002 & 34,5012 & 34,5196 & 5,3848 \\
\hline $\begin{array}{l}\text { Karbon } \\
\text { sesudah } \\
\text { diaktivasi }\end{array}$ & 34,3001 & 34,5002 & 34,6436 & 42,1554 \\
\hline
\end{tabular}

Basa yang digunakan adalah $\mathrm{NH}_{3}$ dan terlihat jelas dari hasil yang didapat bahwa berat $\mathrm{NH}_{3}$ semakin bertambah, hal ini disebakan karena bertambah luasnya permukaan karbon akibat proses aktivasi sehingga memungkinkan lebih banyaknya adsorbat amonia yang teradsorpsi, terlihat pada Tabel 1.

\section{Data absorbansi zat warna metilen biru sesudah diadsorpsi oleh karbon aktif dari kulit kemiri.}

Data hasil pengukuran absorbansi zat warna metilen biru sesudah diadsorpsi oleh karbon aktif dari kulit durian yang diukur dengan spektrofotometer UV-Vis pada panjang gelombang $665 \mathrm{~nm}$ dapat dilihat pada Tabel 2 .

Tabel 2.Absorbansi zat warna metilen biru sesudah diadsorpsi oleh karbon aktif dari kulit kemiri.

\begin{tabular}{lll}
\hline $\begin{array}{l}\text { Filtrat }\left(\mathbf{A}_{\text {ads }}\right) \\
\text { Berat adsorbat }= \\
\mathbf{0 . 1} \mathbf{~ m g / g}\end{array}$ & $\mathbf{F p}$ & $\mathbf{A}_{\mathbf{x}}$ \\
\hline A1 & - & 0,298 \\
A2 & $2 \mathrm{x}$ & 0,342 \\
A3 & $10 \mathrm{x}$ & 0,126 \\
A4 & $10 \mathrm{x}$ & 0,168 \\
A5 & $10 \mathrm{x}$ & 0,085 \\
\hline
\end{tabular}

Keterangan:

Aads $=$ zat warna metilen biru $(\mathrm{A} 1=25 \mathrm{ppm} ; \mathrm{A} 2=55$ ppm; $\mathrm{A} 3=100$ ppm; $\mathrm{A} 4=150$ ppm; $\mathrm{A} 5=200$ ppm)

$\mathrm{A}_{\mathrm{x}}=$ Absorbansi adsorpsi zat warna metilen biru oleh karbon aktif dari kulit kemiri

$\mathrm{Fp}=$ Faktor pengenceran
Berdasarkan data yang diperoleh pada penelitian ini, dapat ditentukan isoterm adsorpsi yang diikuti oleh karbon aktif terhadap zat warna metilen biru dari kulit kemiri. Pengukuran absorbansi larutan standar zat warna metilen biru dari karbon aktif dapat dibuat kurva standar zat warna metilen biru yang ditunjukan pada Tabel 3.

Tabel 3. Data hasil pengukuran kurva standar zat warna Metilen biru

\begin{tabular}{ll}
\hline Konsentrasi & Absorbansi \\
\hline 0,0 & 0,000 \\
0,5 & 0,040 \\
1,0 & 0,128 \\
1,5 & 0,226 \\
2,0 & 0,332 \\
2,5 & 0,426 \\
\hline
\end{tabular}

Untuk menjelaskan adsorpsi zat warna metilen biru oleh karbon aktif pada kulit kemiri, ada dua persamaan isoterm adsorpsi yang umum digunakan yaitu isoterm Langmuir dan Freundlich. Adsorpsi zat warna metilen biru oleh karbon aktif pada kulit kemiri, umumnya menggunakan dua persamaan isoterm adsorpsi yaitu isoterm Langmuir dan Freundlich. Isoterm Langmuir berdasarkan hubungan $C_{e}$ terhadap $\mathrm{C}_{\mathrm{e}} /(\mathrm{x} / \mathrm{m})$, sedangkan isoterm Freundlich berdasarkan hubungan $\mathrm{Ln} \mathrm{C}_{\mathrm{e}}$ terhadap $\operatorname{Ln}(\mathrm{X} / \mathrm{m})$.

Berdasarkan parameter-parameter isoterm Langmuir dan Freundlich di bawah ini (Tabel 4), maka dapat dibuat kurva isoterm Langmuir (Gambar 3) dan kurva isoterm Freundlich (Gambar 4) untuk masing-masing konsentrasi sehingga dapat diketahui isoterm adsorpsi yang sesuai untuk adsorpsi zat warna metilen biru oleh karbon aktif dari kulit kemiri dengan membandingkan nilai koefisien korelasi $\left(\mathrm{r}^{2}\right)$ (Atkins, 1997).

Tabel 4. Parameter-parameter isoterm Langmuir dan Freundlich pada konsentrasi $200 \mathrm{ppm}$

\begin{tabular}{llllllll}
\hline Co & $\mathbf{C e}$ & $\mathbf{C o - C e}$ & $\mathbf{Q}$ & $\mathbf{x} / \mathbf{m}$ & $\mathbf{C e} /(\mathbf{x} / \mathbf{m})$ & $\ln \mathbf{C e}$ & $\ln (\mathbf{x} / \mathbf{m})$ \\
\hline 25 & 1.847 & 23.153 & 92.61 & 5.788 & 0.319 & 0.614 & 1.756 \\
55 & 4.028 & 50.972 & 92.68 & 12.743 & 0.316 & 1.393 & 2.545 \\
100 & 7.282 & 92.718 & 92.72 & 23.180 & 0.314 & 1.985 & 3.143 \\
150 & 9.655 & 140.345 & 93.56 & 35.086 & 0.275 & 2.267 & 3.558 \\
200 & 10.107 & 189.893 & 94.95 & 47.473 & 0.213 & 2.313 & 3.860 \\
\hline
\end{tabular}




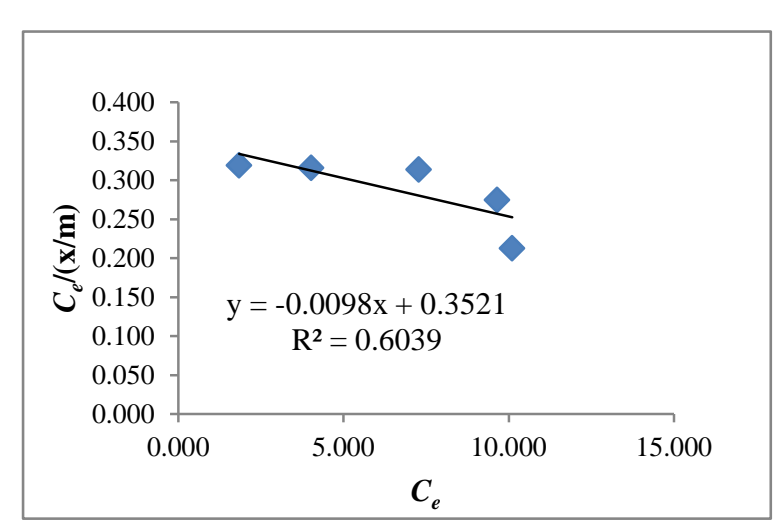

Gambar 3. Kurva isoterm adsorpsi Langmuir

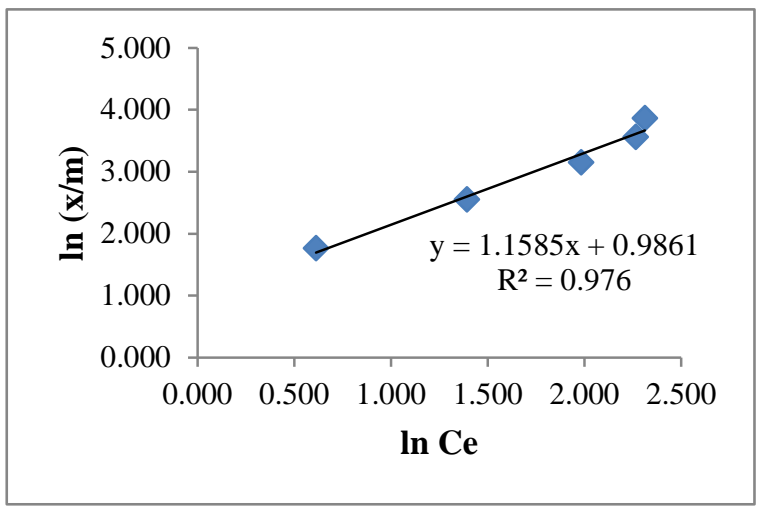

Gambar 4. Kurva isoterm adsorpsi Freundlich

Hubungan linieritas isoterm Langmuir dan Freundlich pada adsorpsi zat warna metilen biru oleh karbon aktif dari kulit kemiriberdasarkan persamaan garis dan koefisien korelasi $\left(\mathrm{r}^{2}\right)$ dapat dilihat pada Tabel 5

Tabel 5. Persamaan garis isoterm adsorpsi Langmuir dan Freundlich

\begin{tabular}{lcc}
\hline \multicolumn{1}{c}{$\begin{array}{c}\text { Isoterm } \\
\text { adsorpsi }\end{array}$} & $\begin{array}{c}\text { Persamaan garis } \\
\text { lurus }\end{array}$ & $\begin{array}{c}\mathbf{r}^{2} \\
(\boldsymbol{\%})\end{array}$ \\
\hline Langmuir & $\mathrm{y}=-0,009 \mathrm{x}+0,352$ & 60,3 \\
Freundlich & $\mathrm{y}=1,158 \mathrm{x}+0,986$ & 97,6
\end{tabular}

Berdasarkan Tabel 4 dapat ditentukan pola isoterm adsorpsi zat warna metilen biru oleh karbon aktif berdasarkan nilai koefisien korelasi $\left(r^{2}\right)$. Dari hasil yang diperoleh pada Tabel 4, nilai koefisien korelasi $\left(\mathrm{r}^{2}\right)$ tertinggi adalah isoterm Freundlich, sehingga dapat dinyatakan bahwa isoterm adsorpsi yang diikuti oleh adsorpsi zat warna metilen biru oleh karbon aktif dari kulit kemiri mengikuti isoterm adsorpsi Freundlich. Isoterm Langmuir hanya berlaku untuk adsorpsi lapisan tunggal pada permukaan adsorben yang bersifat homogen, sedangkan isoterm Freundlich berlaku untuk adsorben yang permukaan bersifat heterogen (Lynam, dkk., 1995). Hal ini menunjukkan bahwa pada larutan yang berkekuatan ion rendah molekul karbon aktif mempunyai poripori yang saling berhubungan. Pori-pori tersebut yaitu pori makro, mikro, dan transisi. Melalui pori inilah terjadi proses penyerapan. Pori makro dapat menyerap molekul adsorbat dan pelarut yang berhubungan dengan permukaan luar dari partikel karbon, pori mikro merupakan cabang dari pori makro dan dapat menyerap pelarut dan adsorbat dengan ukuran yang lebih kecil, sedangkan pori transisi merupakan cabang dari pori mikro yang hanya dapat menyerap molekul pelarut yang lebih kecil. Sehingga dari kulit kemiri, adsorbat yang terbentuk hanya satu lapisan karena permukaan karbon aktif yang bersifat homogen. Pada larutan yang berkekuatan ion tinggi molekul karbon aktif menjadi bentuk acak, sehingga permukaan karbon aktif sebagai adsorben bersifat heterogen karena dapat membentuk lapisan adsorbat dengan ketebalan beberapa lapis (Coocson., 1978).

Dengan menggunakan persamaan isoterm Freundlich pada konsentrasi adsorpsi zat warna metilen biru yang mempunyai nilai optimum dapat dihitung kapasitas atau kemampuan jerap karbon aktif sebagai adsorben. Berdasarkan hasil perhitungan pada Lampiran (4), diperoleh nilai $\mathrm{K}_{\mathrm{F}}$ sebesar $0,0268 \times 10^{2}$ dan $1 / \mathrm{n}$ sebesar 1.163 yang menunjukkan indikator ketergantungan konsentrasi dari besar energi yang berhubungan dengan proses adsorpsi, sehingga nilai $\mathrm{n}=0,8636$. Nilai $\mathrm{K}_{\mathrm{F}}$ menunjukkan kapasitas jerap, semakin besar nilai $\mathrm{K}_{\mathrm{F}}$ maka semakin besar kapasitas adsorben menyerap adsorbat (Lynam, dkk., 1995) dan dibenarkan oleh penelitian ini yang menghasilkan nilai $\mathrm{K}_{\mathrm{F}}$ sebesar $0,0268 \times 10^{2} \mathrm{mg}$ $\mathrm{g}^{-1}$ lebih besar jika dibandingkan dengan hasil penelitian yang diperoleh Tutupary (2010) yaitu sebesar $0,0353 \quad \mathrm{mg}^{-1}$. Nilai $\mathrm{n}>1$ mengindikasikan baiknya penjerapan zat warna metilen biru oleh karbon aktif (Zor, 2004). Berdasarkan data di atas maka dapat diindikasikan bahwa adanya perlakuan karbon aktif memberikan nilai $\mathrm{n}$ yang berkurang. Hal ini diduga, karena permukaannya yang kecil dan bersifat selektif sehingga pada campuran 


\section{J. Latupeirissa dkk. / Indo. J. Chem. Res, 2018, 6(1), 12-21}

zat, ada beberapa komponen yang terserap oleh zat padat tertentu (Cheremisinoff, dkk., 1978).

\section{Penentuan orde reaksi dan tetapan laju adsorpsi}

Dalam menentukan orde dan tetapan laju adsorpsi digunakan konsentrasi zat warna metilen biru dan karbon aktif yang mempunyai adsorpsi optimum sesuai dengan hasil yang diperoleh pada Tabel 3 yaitu pada konsentrasi $200 \mathrm{ppm}$. Selanjutnya dilakukan pengukuran dengan variasi waktu mulai dari 30 menit sampai 360 menit pada suhu $25{ }^{\circ} \mathrm{C}$ yang hasilnya dapat dilihat pada Tabel 6.

Tabel 6. Absorbansi larutan zat warna metilen biru yang telah teradsorpsi oleh karbon aktif dengan konsentrasi 200 ppm pada suhu $25{ }^{\circ} \mathrm{C}$

\begin{tabular}{lll}
\hline Waktu (t, menit) & Fp & Absorbansi \\
\hline 30 & $20 \mathrm{x}$ & 0,332 \\
60 & $20 \mathrm{x}$ & 0,522 \\
90 & $20 \mathrm{x}$ & 0,596 \\
120 & $20 \mathrm{x}$ & 0,572 \\
150 & $20 \mathrm{x}$ & 0,586 \\
180 & $20 \mathrm{x}$ & 0,260 \\
240 & $20 \mathrm{x}$ & 0,254 \\
360 & $20 \mathrm{x}$ & 0,301 \\
\hline
\end{tabular}

\section{Model kinetika adsorpsi Lagergren orde satu-semu}

Model kinetika adsorpsi Lagergren orde satu-semu zat warna metilen biru oleh karbon aktif dari kulit kemiri pada konsentrasi 200 ppm pada suhu $25{ }^{\circ} \mathrm{C}$ dengan nilai parameterparameter yang digunakan dapat dilihat pada Tabel 7.

Tabel 7. Model kinetika adsorpsi Lagergren orde satu- satu-semu zat warna metilen biru oleh karbon aktif dari kulit kemiri dengan

konsentrasi konsentrasi 200 ppm pada suhu $30^{\circ} \mathrm{C}$.

\begin{tabular}{lllll}
\hline \multicolumn{2}{c}{ Persamaan Kinetika } & $\begin{array}{c}\mathbf{r}^{2} \\
(\%)\end{array}$ & \multicolumn{2}{c}{ Xe (mg/g) } \\
\cline { 3 - 5 } \multicolumn{2}{c}{} & & $\begin{array}{c}\text { Xe yang } \\
\text { dicoba }\end{array}$ & $\begin{array}{c}\text { Xe yang } \\
\text { dihitung }\end{array}$ \\
\hline $\ln \left(X_{e}-X\right)=\ln X_{e}-k_{1, a d s}{ }^{t}$ & 27,74 & 50 & $-0,545 \times 10^{-3}$ \\
& 26,38 & 55 & $-0,193 \times 10^{-4}$ \\
\hline
\end{tabular}

Hasil perhitungan pada Tabel 7 diperoleh dari nilai parameter-parameter yang digunakan pada Tabel 8 dengan nilai $\mathrm{X}_{\mathrm{e}}$ yang dicoba $=50$ $\mathrm{mg} / \mathrm{g}$.

Tabel 8. Parameter-parameter model kinetika adsorpsi Lagergren orde satu-semu zat warna metilen biru oleh karbon aktif dari kulit kemiri dengan konsentrasi $200 \mathrm{ppm}$ dan nilai $\mathrm{X}_{\mathrm{e}}$ yang dicoba $=50 \mathrm{mg} \mathrm{g}^{-1}$ pada suhu $25^{\circ} \mathrm{C}$

\begin{tabular}{lccccccc}
\hline $\begin{array}{c}\mathbf{t} \\
(\mathbf{m e n i t})\end{array}$ & Abs & $\mathbf{F p}$ & $\begin{array}{c}\mathbf{C e} \\
(\mathbf{p p m})\end{array}$ & $\begin{array}{c}\mathbf{C a d s} \\
(\mathbf{p p m})\end{array}$ & $\begin{array}{c}\mathbf{X} \\
\left(\mathbf{m g ~ g}^{-1}\right)\end{array}$ & $\begin{array}{c}(\mathbf{X e}-\mathbf{X}) \\
\left(\mathbf{m g ~ g}^{-1}\right)\end{array}$ & $\begin{array}{c}\mathbf{I n}(\mathbf{X e}-\mathbf{X}) \\
\left(\mathbf{m g ~ g}^{-1}\right)\end{array}$ \\
\hline 30 & 0,332 & $20 \mathrm{x}$ & 6,804 & 193,196 & 48,299 & 1,701 & 0,531 \\
60 & 0,522 & $20 \mathrm{x}$ & 10,604 & 189,396 & 47,349 & 2,651 & 0,975 \\
90 & 0,596 & $20 \mathrm{x}$ & 12,084 & 187,916 & 46,979 & 3,021 & 1,106 \\
120 & 0,572 & $20 \mathrm{x}$ & 11,604 & 188,396 & 47,099 & 2,901 & 1,065 \\
150 & 0,586 & $20 \mathrm{x}$ & 11,884 & 188,116 & 47,029 & 2,971 & 1,089 \\
180 & 0,260 & $20 \mathrm{x}$ & 5,364 & 194,636 & 48,659 & 1,341 & 0,293 \\
240 & 0,254 & $20 \mathrm{x}$ & 5,244 & 194,756 & 48,689 & 1,311 & 0,271 \\
360 & 0,301 & $20 \times$ & 6,184 & 193,816 & 48,454 & 1,546 & 0,436 \\
\hline
\end{tabular}

Dengan menggunakan data pada Tabel 8 maka dapat dibuat kurva $\mathrm{t}$ vs $\ln \left(\mathrm{X}_{\mathrm{e}}-\mathrm{X}\right)$ untuk model kinetika adsorpsi Lagergren orde satu semu seperti terlihat pada Gambar 5. Nilai koefisien korelasi $\left(\mathrm{r}^{2}\right)$ yang diperoleh dari kurva pada Gambar 6 sebesar 27,74 \% yang berarti bahwa kinetika adsorpsi zat warna metilen biru oleh karbon aktif dari kulit kemiri dengan konsentrasi 200 ppm tidak mengikuti model kinetika adsorpsi Lagergren orde satu-semu karena nilai koefisien korelasinya di bawah 95 $\%$.

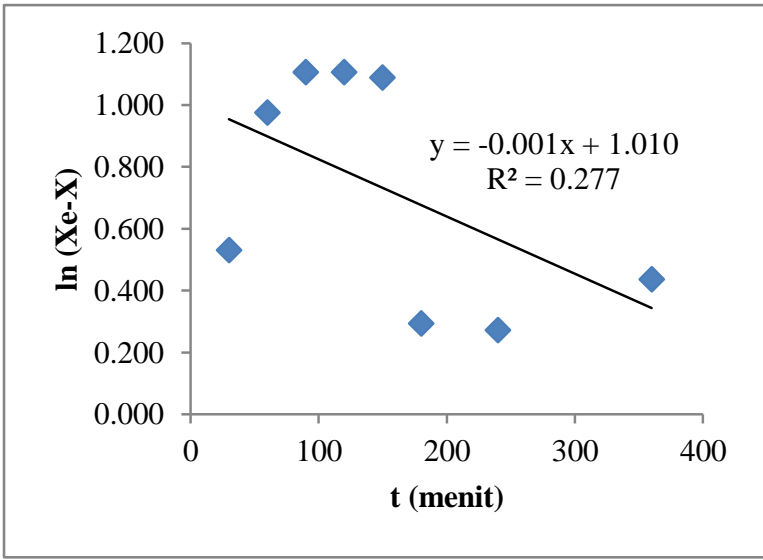

Gambar 5. Kurva kinetika adsorpsi Lagergren orde satu-semu dengan $\mathrm{X}_{\mathrm{e}}$ yang dicoba $=50 \mathrm{mg} / \mathrm{g}$. 


\section{J. Latupeirissa dkk. / Indo. J. Chem. Res, 2018, 6(1), 12-21}

Pada sistem adsorpsi karbon aktif-metilen biru pada konsentrasi 200 ppm untuk suhu 25 ${ }^{\circ} \mathrm{C}$, nilai Xe yang dicoba adalah $50 \mathrm{mg} \mathrm{g}^{-1}$ yang menghasilkan persamaan garis lurus $\ln (\mathrm{Xe}-\mathrm{X})$ $=-0,001 \mathrm{x}-1,010$ dengan $\mathrm{r}^{2}=27,74 \%$ dan Xe yang dihitung adalah $-0,545 \times 10^{-3} \mathrm{mg} \mathrm{g}^{-1}$ (Tabel 7).

\section{Model kinetika adsorpsi Lagergren orde dua-semu}

Pengolahan data hasil penjerapan model kinetika adsorpsi Lagergren orde dua-semu zat warna metilen biru oleh karbon aktif pada konsentrasi 200 ppm dapat dilihat pada Tabel 9 dan Gambar 6.

Tabel 9. Parameter-parameter model kinetika adsorpsi Lagergren ordeDua semu zat warna metilen biru pada konsentrasi 200 ppm pada

\begin{tabular}{|c|c|c|c|c|}
\hline $\begin{array}{c}\mathbf{t} \\
\text { (waktu) }\end{array}$ & $\begin{array}{c}\mathbf{C e} \\
(\mathbf{p p m})\end{array}$ & $\begin{array}{c}\text { Cads } \\
(\mathbf{p p m})\end{array}$ & $\begin{array}{c}\mathrm{X} \\
(\mathrm{mg} \mathrm{g}-1) \\
\end{array}$ & $\begin{array}{c}\mathrm{t} / \mathbf{X} \\
\left(\text { menit } \mathrm{mg} \mathrm{g}^{-1} \text { ) }\right. \\
\end{array}$ \\
\hline 30 & 6,804 & 193,196 & 48,299 & 0,621 \\
\hline 60 & 10,604 & 189,396 & 47,349 & 1,267 \\
\hline 90 & 12,084 & 187,916 & 46,979 & 1,916 \\
\hline 120 & 11,604 & 188,396 & 47,099 & 2,548 \\
\hline 150 & 11,884 & 188,116 & 47,029 & 3,190 \\
\hline 180 & 5,364 & 194,636 & 48,659 & 3,699 \\
\hline 240 & 5,244 & 194,756 & 48,689 & 4,929 \\
\hline 360 & 6,184 & 193,816 & 48,454 & 7,430 \\
\hline
\end{tabular}

Dengan menggunakan data pada Tabel 9 maka dapat dibuat kurva $t$ vs $t / x$ untuk model kinetika adsorpsi Lagergren orde dua-semu seperti terlihat pada Gambar 6.

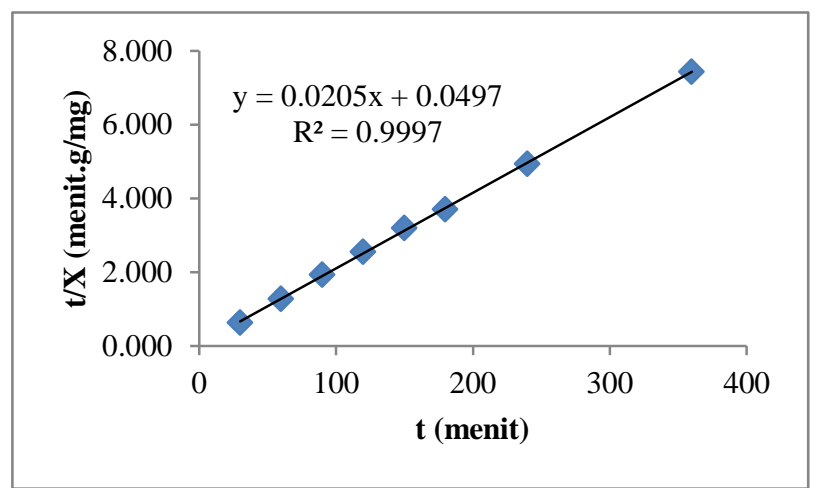

Gambar 6. Kurva kinetika adsorpsi Lagergren orde dua - semu

Nilai koefisien korelasi $\left(\mathrm{r}^{2}\right)$ yang diperoleh dari kurva pada Gambar 6 sebesar 99,9\%menunjukkan bahwa model kinetika adsorpsi zat warna metilen biru oleh karbon aktif pada konsentrasi 200 ppm mengikuti model adsorpsi Lagergren orde dua-semu dengan $\mathrm{Xe}=49,02 \mathrm{mg} \mathrm{g}^{-1}$ dan $\mathrm{k}_{2, \mathrm{ads}}=0,00788 \mathrm{~g}$ $\mathrm{mg}^{-1}$ menit ${ }^{-1}$. Hasil penelitian ini dibandingkan dengan yang dilakukan oleh Abechi, dkk (2011) bahwa kinetika adsorpsi zat warna metilen biru oleh karbon aktif dari kulit kelapa sawit samasama mengikuti model kinetika adsorpsi orde dua, meskipun menggunakan karbon aktif yang berbeda.

\section{Mekanisme Adsorpsi Zat Warna Metilen Biru Oleh Karbon Aktif Dari Kulit kemiri.}

Mekanisme proses adsorpsi zat warna metilen biru pada konsentrasi 200 ppm dapat dijelaskan dengan mengasumsikan bahwa sebagai penentu laju reaksi adalah proses penjerapan kimia yang meliputi gaya antar valensi atau pertukaran elektron antara adsorbent dan adsorbat. Ini berarti sebagai penentu laju proses adsorpsi yaitu proses pengambilan yang berupa penjerapan kimiafisik dengan proses pengambilan yang berlangsung paling lambat yaitu saat proses adsorpsi, terjadi interaksi elektrostatik antara zat warna metilen biru yang bermuatan positif dengan karbon aktif yang bermuatan negatif (Allen,dkk., 1997).

Difusi intra partikel bergantung pada beberapa faktor seperti struktur sorben, sifat fisik sorben dan sorbat, sifat-sifat kimia sorbat, interaksi sistem dan kondisi sistem. Mekanisme difusi intra partikel didasarkan pada dua mekanisme yaitu difusi pori dan difusi padat. Difusi pori bergantung pada transport pelarut dan struktur internal dari pori-pori sorben. Mekanisme ini menjelaskan difusi molekul sorbat ke dalam partikel dalam cairan dan dalam pori-pori cairan (Allen,dkk., 1997).

\section{Penentuan energi aktivasi}

Penentuan energi aktivasi dilakukan pada konsentrasi zat warna dan kadar garam yang mempunyai adsorpsi optimum yaitu konsentrasi zat warna biru metilen $200 \mathrm{ppm}$ dengan memvariasikan suhu $25{ }^{\circ} \mathrm{C}$ dan $30{ }^{\circ} \mathrm{C}$. Adapun hasil absorbansi pada variasi waktu dapat dilihat pada Tabel 6 untuk $25{ }^{\circ} \mathrm{C}$ dan Tabel 10 untuk $30{ }^{\circ} \mathrm{C}$.

Pada umumnya adsorpsi merupakan proses eksotermis, $\Delta \mathrm{H}_{\mathrm{ads}}<0$. Proses ini digambarkan dengan meningkatnya suhu bila adsorbat 


\section{J. Latupeirissa dkk. / Indo. J. Chem. Res, 2018, 6(1), 12-21}

berinteraksi dengan adsorben. Besarnya energi yang terlibat dalam adsorpsi, ditentukan dengan menggunakanpersamaan Arrhenius yaitu: $\mathrm{E}_{\mathrm{a}}=$ RT ln k Berdasarkan hasil penelitian ini yang mengikuti mekanisme adsorpsi kimia (kemisorpsi), maka jumlah zat yang teradsorpsi akan makin besar dengan naiknya suhu. Oleh karenaitu, maka untuk melepaskan kembali adsorbat dari permukaan adsorben diperlukan banyak energi.

Tabel 10. Absorbansi larutan zat warna biru metilena yang telah teradsorpsi oleh karbon aktif dengan konsentrasi 200 ppm pada suhu $30{ }^{\circ} \mathrm{C}$.

\begin{tabular}{ccc}
\hline $\begin{array}{c}\text { Waktu } \\
\text { (t,menit) }\end{array}$ & Fp & Absorbansi \\
\hline 30 & $20 \mathrm{x}$ & 0,348 \\
60 & $20 \mathrm{x}$ & 0,414 \\
90 & $20 \mathrm{x}$ & 0,587 \\
120 & $20 \mathrm{x}$ & 0,432 \\
150 & $20 \mathrm{x}$ & 0,355 \\
180 & $20 \mathrm{x}$ & 0,498 \\
240 & $20 \mathrm{x}$ & 0,264 \\
360 & $20 \mathrm{x}$ & 0,127 \\
\hline
\end{tabular}

Pada penelitian ini, orde reaksi yang diikuti oleh adsorpsi karbon aktif terhadap zat warna biru metilena adalah orde dua dan dengan menggunakan nilai $\mathrm{k}_{2 \text {,ads }}$ pada suhu 25 ${ }^{\circ} \mathrm{C}$ dan suhu $30{ }^{\circ} \mathrm{C}$, sehingga dapat dibuat suatu perhitungan untuk menentukan nilai energi aktivasi $\left(\mathrm{E}_{\mathrm{a}}\right)$ dengan menggunakan parameterparameter seperti yang dapat dilihat pada Tabel 11.

Tabel 11. Parameter-parameter penentuan energi aktivasi

\begin{tabular}{lllll}
\hline $\begin{array}{l}\text { Suhu } \\
\left({ }^{\circ} \mathrm{C}\right)\end{array}$ & $\begin{array}{c}\mathrm{k}_{2}, \mathrm{ads} \\
\left(\mathrm{g} \mathrm{mg}^{-1}\right. \\
\left.\text { menit }^{-1}\right)\end{array}$ & $\begin{array}{l}\mathrm{T} \\
(\mathrm{K})\end{array}$ & $\begin{array}{l}1 / \mathrm{T} \\
\left(\mathrm{K}^{-1}\right)\end{array}$ & $\begin{array}{c}\text { ln k2, ads } \\
\left(\mathrm{g} \mathrm{mg}^{-1} \mathrm{menit}^{-1}\right)\end{array}$ \\
\hline 25 & 0,00788 & 298 & $3,3557 \times 10^{-3}$ & $-4,8434$ \\
30 & 0,00579 & 303 & $3,3003 \times 10^{-3}$ & $-5,1516$ \\
\hline
\end{tabular}

Dengan menggunakan data pada Tabel 11 dibuat perhitungan untuk menghitung energi aktivasi $\left(E_{a}\right)$. Berdasarkan hasil perhitungan pada diperoleh energi aktivasi $\left(\mathrm{E}_{\mathrm{a}}\right)$ sebesar $-46,24310602 \mathrm{~kJ} \mathrm{~mol}^{-1}$ dan faktor praeksponensial (A) sebesar $1,61975 \times 10^{-10} \mathrm{~g}$ $\mathrm{mg}^{-1}$ menit $^{-1}$. Hasil yang diperoleh ini sangat dipengaruhi oleh suhu dalam meningkatkan kapasitas adsorpsi, maka dengan meningkatnya suhu, kapasitas adsorpsi juga meningkat.

\section{KESIMPULAN}

Berdasarkan hasil yang diperoleh maka dapat disimpulkan sebagai berikut:

1. Adsorpsi zat warna metilen biru oleh akrbon aktif dari kulit kemiri mengikuti isoterm adsorpsi Freundlich.

2. Model kinetika adsorpsi metilen biru oleh karbon aktif dari kulit kemiri mengikuti model adsorpsi Lagergren orde dua-semu dengan nilai konstanta laju reaksi $(\mathrm{k} 2$,ads) sebesar $0,00788 \mathrm{~g} \mathrm{mg}^{-1}$ menit $^{-1}$ dan $\mathrm{X}_{\mathrm{e}}$ sebesar $49,02 \mathrm{mg} \mathrm{g}^{-1}$. Diperoleh juga nilai energi aktivitas sebesar-46,24310602 $\mathrm{KJ} / \mathrm{mol}$ dan nilai A sebesar sebesar $1,61975 \times 10^{-10} \mathrm{~g} \mathrm{mg}^{-1}$ menit ${ }^{-1}$. Mekanisme adsorpsi metilen biru oleh karbon aktif dari kulit kemiri mengasumsikan bahwa penentuan laju reaksi adalah proses adsorpsi kimia.

\section{DAFTAR PUSTAKA}

Abechi E.S, Gimba C.E, Uzairu A, Kagbu J.A., 2011, Kinetics of adsorption of methylene blue onto activated carbon prepared from palm kernel shell, Archives of Applied Science Research, 3 (1), 154-164.

Allen, S,J., Whitten, L.J, Murray, M., Duggan, O., Brown, P., 1997, The Adsorption of Pollutants by Peat, Lignite and Actived Chars, J.Chem Tech. Biotechnol, 68, 442452.

Atkins, P. W., 1990, Kimia Fisika Jilid 2 Edisi Keempat, Penerjemah I.I. Kartohadiprodjo. Penerbit Erlangga. Jakarta.

Cheremisinoff, Morresi, 1978, Carbon Adsorption Hand Book. Ann Arbor Science Publishers. Universitas Michigan

Coocson, 1978, Adsorption Mechanisme The Chemistry of Organic Application, Ann Arbor.

Demirbas, A., 2009, Agricultural based Activated Carbons for the removal of dyes from aqueous Solutions: A review, Eng. J., 167, 1-9.

Fessenden, R. J, Fessenden, J. S, 1984, Kimia Organik II Edisi kedua, Terjemahan A. Hadyana Pudjaatmaka, Penerbit Erlangga, Jakarta. 


\section{J. Latupeirissa dkk. / Indo. J. Chem. Res, 2018, 6(1), 12-21}

Latupeirissa, J., Tanasale, M.F.J.D.P., Dade, K., 2017, Carbon characterization from candlenut shells (Aleurites moluccana (L) Wild) with X-RD, Indo. J. Chem. Res., 3(1), $326-330$.

Lynam, M. M., Kilduff, J. E., Weber, W. J. Jr., 1995, Adsorption of p-nitrophenol from Dilute Aquadeous Solution, J. Chem Edu, 72, 80-84.

Rini. P., Sutapa. J. P. G., 2005, Mutu Arang Aktif dar Limbah Кауи Mahoni sebagai Bahan Penjernih Air, Fakultas Kehutanan UGM, Yogyakarta

Tutupary, F. J., 2010, Kinetika Adsorpsi Zat Warna Biru Metilena 0leh Kitosan Pada Beberapa Kadar Garam, Skripsi Sarjana, Jurusan Kimia FMIPA Unpatti, Ambon.
Widhianti, W. D., 2010, Pembuatan Arang Aktif dari Biji Kapuk (Ceiba pentandra L.) sebagai Adsorben Zat Warna Rhodamin B, Skripsi Sarjana, Departemen Kimia, Fakultas Sains dan Teknologi, Universitas Airlangga, Surabaya.

Zor, S., 2004, Investigation of the Adsorption of Anionic Surfacftans of Different $\mathrm{pH}$ Values by Means of Active Carbon and the Kinetics of Adsorption, J. Serh. Chem. Soc, 69, $25-32$. 